\title{
Taxonomy and pathogenicity of two novel Chrysoporthe species from Eucalyptus grandis and Syzygium guineense in Zambia
}

\author{
Donald Chungu ${ }^{1}$, Marieka Gryzenhout ${ }^{1}$, Ambayeba Muimba-Kankolongo ${ }^{2}$, Michael J. \\ Wingfield $^{1}$ and Jolanda Roux ${ }^{1}$
}

(1) Department of Microbiology and Plant Pathology, Forestry and Agricultural Biotechnology Institute (FABI), University of Pretoria, Pretoria, 0002, South Africa

(2) School of Natural Resources, Copperbelt University, P.O. Box 21692, Kitwe, Zambia

\section{Donald Chungu}

Email: donald.chungu@fabi.up.ac.za

\begin{abstract}
Among fungi in the Cryphonectriaceae, Cryphonectria parasitica, the causal agent of chestnut blight, and Chrysoporthe spp., inducing stem cankers and death of plantation-grown Eucalyptus spp., constitute some of the most important tree pathogens. During a survey to determine diseases and related pathogens associated with native and non-native Myrtales in Zambia, two fungi resembling stem canker pathogens in the genus Chrysoporthe were recovered from Syzygium guineense and Eucalyptus grandis. We undertook this study to characterise the fungi, using DNA sequence comparisons and morphological features. Inoculation tests were also conducted in a greenhouse to assess their pathogenicity on Eucalyptus spp. Results showed distinct phenotypic differences between isolates collected from Zambia and existing species of Chrysoporthe, and phylogenetic analyses demonstrated that the Zambian isolates represent previously undescribed species of Chrysoporthe. These isolates, which have been named Chrysoporthe zambiensis sp. nov. and Chrysoporthe syzygiicola sp. nov., are only known from their anamorphic states. Both species were found to be pathogenic to Eucalyptus. The description of Chr. zambiensis and Chr. syzygiicola with teleomorph names, led to the new combination Chrysoporthe hodgesiana for the only anamorphic species in Chrysoporthe, Chrysoporthella hodgesiana, to ensure more stable and less confusing taxonomy for Chrysoporthe.
\end{abstract}

\section{Introduction}

The Cryphonectriaceae is a recently established fungal family in the Diaporthales that includes several genera accommodating important tree pathogens (Gryzenhout et al. 2006a, 2009). For example, Cryphonectria parasitica, the causal organism of chestnut blight, has devastated the American chestnut (Castanea dentata) in North America and European chestnut (Castanea sativa) in Europe (Anagnostakis 1987; Heiniger and Rigling 1994). Similarly, Chrysoporthe cubensis and Chr. austroafricana have been reported as economically important pathogens of Eucalyptus spp. and other Myrtales in many tropical and sub-tropical countries (Gibson 1981; Hodges et al. 1985; Wingfield et al. 1989; Gryzenhout et al. 2006b; Nakabonge et al. 2006). The devastating nature of the disease caused by Chr. cubensis and Chr. austroafricana has been an important motivating factor in the development and deployment of hybrid and clonal Eucalyptus forestry in South America and South Africa (Wingfield 2003). 
Chrysoporthe cubensis has been known in Africa since the middle of the last century. The pathogen was first reported in 1952, as Endothia eugeniae, causing dieback of clove trees (Syzygium aromaticum) in Zanzibar (Nutman and Roberts 1952). On Eucalyptus spp., the fungus was first found in the Republic of Congo and thought to represent Cryphonectria havanensis (Hodges et al. 1985), but it was later identified as Chr. cubensis (Micales et al. 1987; Gryzenhout et al. 2004). Chrysoporthe cubensis has also been reported to cause disease of young E. urophylla in Cameroon (Gibson 1981), of E. grandis and E. urophylla in the Republic of Congo (Roux et al. 2003) and of Eucalyptus spp. in Mozambique and Kenya (Nakabonge et al. 2006). A recent study by Nakabonge et al. (2007) has suggested that Chr. cubensis is an introduced pathogen to Africa, with some strains originating from South America and others from Asia (Roux et al. 2003; Gryzenhout et al. 2006b).

Chrysoporthe austroafricana is an economically important pathogen of commercially grown Eucalyptus spp. in Africa (Wingfield 2003; Gryzenhout et al. 2004; Nakabonge et al. 2006). In South Africa, the pathogen caused substantial damage to plantation forestry and was partially managed through the selection and planting of disease tolerant clones (Wingfield et al. 1989; Wingfield 2003). The recent discovery of Chr. austroafricana on native Syzygium trees and Eucalyptus spp. in Malawi, Mozambique, Zambia (Roux et al. 2005; Nakabonge et al. 2006), Namibia (Vermeulen et al. 2008) and South Africa (Heath et al. 2006) has changed views regarding its origin. Once considered an introduced pathogen to Africa (Wingfield et al. 1989; Van Heerden and Wingfield 2001), Chr. austroafricana is currently suggested to be native to Africa, where it has undergone a host shift (Slippers et al. 2005) from native to non-native trees on the continent (Heath et al. 2006).

In Zambia, Chr. austroafricana was reported on Syzygium trees and Eucalyptus spp. from Kitwe on the Copperbelt region (Roux et al. 2005; Nakabonge et al. 2006). Whether this and other species in the Cryphonectriaceae also occur in other regions of the country is not known. Plantation forestry is increasing in importance in Zambia, becoming one of the major sources of income and employment for the population (Zimba 2005). This has necessitated the need to fully understand the potential impact of diseases on forest trees in order to suggest disease management strategies in the country. For this, surveys were conducted in several locations to establish the occurrence of the Cryphonectriaceae on native Syzygium trees and on introduced Eucalyptus spp., and to characterise these fungi using DNA sequences, morphological characteristics and pathogenicity tests.

\section{Materials and Methods}

\section{Collection of samples}

Isolates used in this study were obtained from stem cankers on Eucalyptus spp. (Myrtales) and Syzygium spp. (Myrtales) during surveys conducted in different geographical areas in Zambia between 2007 and 2008 (Fig. 1). Fungal fruiting structures from stem cankers were first tested for a purple discoloration in 3\% potassium hydroxide $(\mathrm{KOH})$ to confirm the affiliation to the Cryphonectriaceae (Gryzenhout et al. 2006a). Isolations were made by lifting spore drops from fresh fruiting structures with a sterile needle and transferring these to $2 \%$ malt extract agar (MEA) [20 g/l agar and $15 \mathrm{~g} / 1$ malt extract (Biolab, Midland, Johannesburg) containing $100 \mathrm{mg} / \mathrm{l}$ streptomycin sulphate (Sigma-Aldrich, Steinheim, Germany)]. Single spore cultures were incubated at $25^{\circ} \mathrm{C}$ under florescent light for 10 days to obtain pure cultures and sufficient mycelium for DNA extraction. All isolates are maintained in the Culture Collection (CMW) of the Forestry and Agricultural Biotechnology Institute (FABI), University of Pretoria, South Africa. Representative isolates have also been deposited in the CBS (Centraalbureau voor Schimmelcultures, The Netherlands) and linked bark material in the National Collection of Fungi, Pretoria (PREM). 


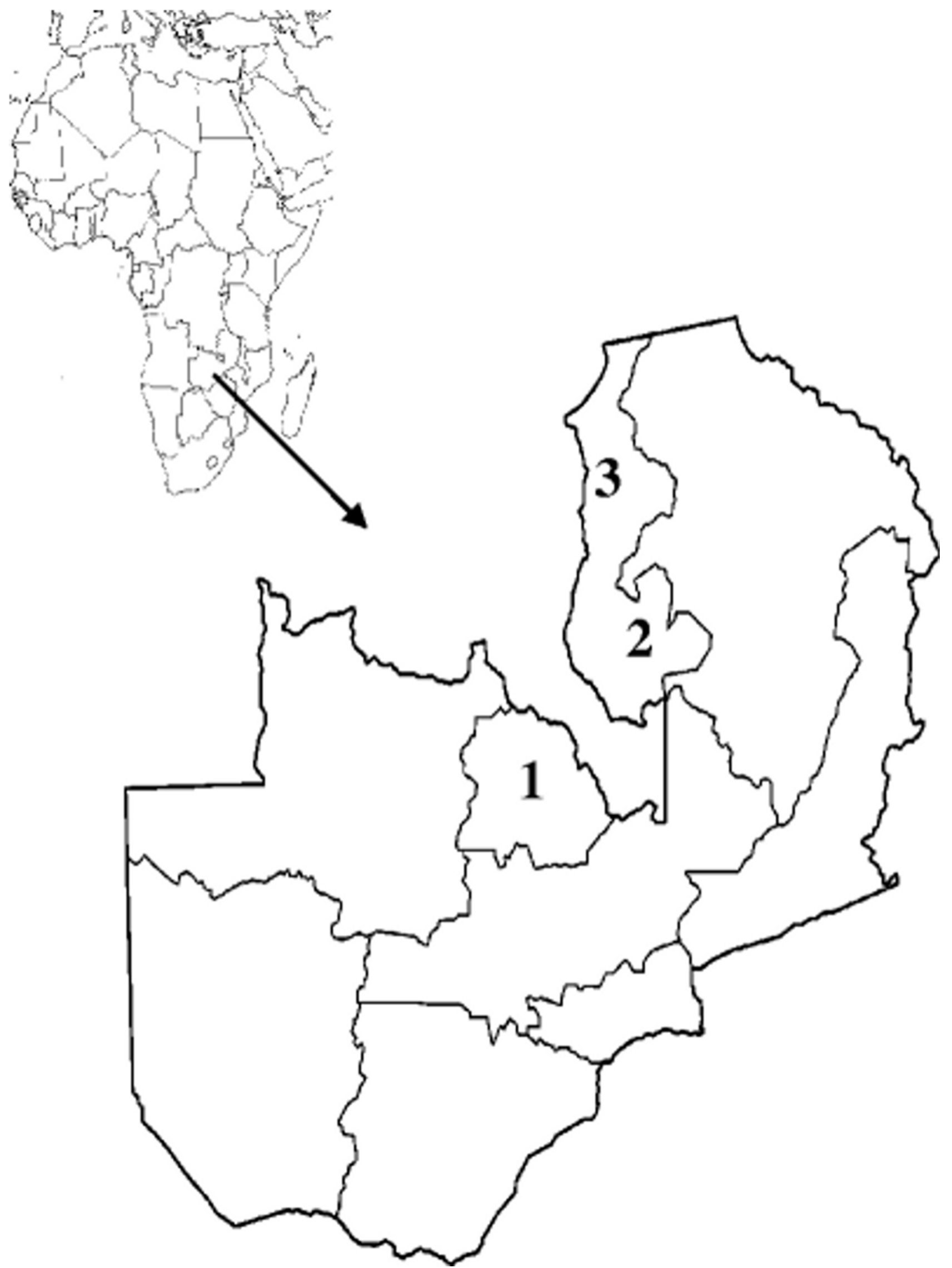

Fig. 1. Map of Zambia showing locations where Chrysoporthe species were collected. 1

Chrysoporthe austroafricana in Kitwe, Copperbelt Province (Nakabonge et al. 2006). 2 Chr. syzygiicola on Syzygium guineense in Samfya, Luapula Province. 3 Chr. zambiensis on Eucalyptus grandis in Kapweshi, Luapula Province. 


\section{DNA extraction}

Isolates for DNA extraction were selected from each host, geographic area of Zambia and morphological group. Mycelium from actively growing cultures of isolates was harvested, separately placed in 1.5-ml sterile Eppendorf tubes, freeze-dried and ground to a fine powder using sterile metal beads on a Mixer Mill (Type MM 301, Retsch ${ }^{\circledR}$ tissue lyser; Retsch, Germany) for 2 min at 45 cycles/s. DNA were extracted and purified using the Cetyl Trimethyl Ammonium Bromide (CTAB) method (Möller et al. 1992) and concentrations were determined using a Nanodrop ND-1000 Spectrophotometer v. 3.6 (Thermo Fisher Scientific, Wilmington, USA). After extraction, DNA were used as a template for amplification with the polymerase chain reaction (PCR). Internal transcribed spacer (ITS) regions ITS1 and ITS2, and the conserved 5.8 S gene of the ribosomal DNA were amplified using primers ITS1 and ITS4 (White et al. 1990). The $\beta$-tubulin gene region was amplified using primers Bt1a with Bt1b and Bt2a with Bt2b (Glass and Donaldson 1995). PCR reaction mixtures were prepared in a total volume of $25 \mu \mathrm{l}$ as described by Gryzenhout et al. (2009).

PCR products were visualised on $2 \%$ agarose gels containing ethidium bromide under ultra-violet light. Sizes of PCR amplicons were estimated by comparison against a 100-bp molecular weight marker (O'RangeRuler ${ }^{\text {TM }} 100$-bp DNA ladder) (Fermentas Life Sciences, USA). Prior to DNA sequencing, PCR products were purified using Centri-sep spin columns (Princeton Separations, Adelphina, NJ) containing Sephadex G-50 (Sigma Aldrich, Amersham Biosciences, Sweden) as outlined by the manufacturer.

\section{DNA sequencing and phylogenetic analyses}

Purified PCR products were used as template DNA for cycle sequencing reactions using the ABI Prism Big Dye Terminator Cycle sequencing reaction kit v. 3.1 (Applied Biosystems, Foster City, CA) following the manufacturer's protocol. The same primers for PCR reactions were also used for sequencing reactions run by an ABI PRISM ${ }^{\mathrm{TM}} 3100$ Autosequencer (Applied Biosystems). Sequence electropherograms were analysed using Sequence Navigator version 1.0.1 (Applied Biosystems) to obtain both the forward and reverse sequences for each isolate. Sequences were then matched and analysed using Sequence Navigator version 1.0.1 (Applied Biosystems). Additional sequences for comparison were obtained from Genbank as published by Gryzenhout et al. (2004, 2005). For the purpose of this study, sequence alignments were done using the online interface (http://align.bmr.kyushu-u.ac.jp/mafft/software/) of MAFFT v. 5.667 (Katoh et al. 2002) incorporating the G-INS-i alignment algorithm. Alignments were checked and adjusted manually if sequences were not satisfactorily aligned by MAFFT.

Phylogeny of aligned sequences was determined using PAUP* 4.0 (Swofford 2002). A partition homogeneity test (PHT) (Farris et al. 1994) was applied to the combined data of rDNA ITS and $\beta$ tubulin sequences prior to exclusion of uninformative sites, using 1,000 replicates, to ascertain whether they could be collectively analysed. All gaps were coded as missing data and characters were assigned equal weight. The Heuristic search option with random stepwise addition and tree bisection reconnection (TBR) was used as the swapping algorithm. The Mulpar option was in effect and branches collapsed if they equalled zero. Confidence levels of the branching points were determined using 1,000 bootstrap replicates and distribution of 1000 trees.

Modeltest version 3.04 (Posada and Crandall 1998) was used to determine the most appropriate nucleotide substitution model to be applied to the combined DNA sequence alignment and $\mathrm{GTR}+\mathrm{I}+\mathrm{G}$ was chosen from the Akaike Information Criterion (AIC). Following this, a neighbourjoining (NJ) analysis using the GTR $+\mathrm{I}+\mathrm{G}$ substitution model (Yang 1994) was conducted in PAUP. Here, identical sites were removed proportionally to base frequencies estimated from all sites, and 
rates of invariable sites assumed to follow a gamma distribution and ties were broken if encountered. For phylogenetic analyses, Cryphonectria parasitica and C. japonica were used as the outgroup taxa and treated as paraphyletic sister groups to the in-groups.

\section{Morphological characteristics}

Fungal fruiting structures were cut from bark specimens, rehydrated for $1 \mathrm{~min}$ in boiling water and mounted in Jung Tissue Freezing Medium (Leica Microsystems, Wetzlar, Germany). Thin sections $(10 \mu \mathrm{m})$ were cut using a Leica CM 100 Freezing microtome (Leica Microsystems) and mounted on slides in $85 \%$ lactic acid. Both cross-sections and structures obtained from fruiting bodies were examined under a Zeiss Axioskop light microscope (Carl Zeiss, Jena, Germany) using differential interference contrast. Sixty measurements of conidia and conidiophores for all specimens were taken from fresh slides at $\times 1,000$ magnification. These are presented as $(\mathrm{min}-)$ (average - standard deviation $)-($ average + standard deviation $)(-\max ) \mu \mathrm{m}$. Morphological characteristics of the fungi from Zambia were then compared with those of Chrysoporthe spp. known to occur on Eucalyptus spp. and other hosts from other countries (Gryzenhout et al. 2009).

An in vitro growth study was conducted on two groups of unidentified isolates, designated Group One (CMW29928, CMW29930) and Group Two (CMW29940, CMW29941), and Chr. austroafricana isolates (CMW2113, CMW9328, CMW13975) from South Africa and Zambia (Table 1). Agar plugs ( $5 \mathrm{~mm}$ diameter) from 7-day-old, single conidial colonies of each isolate were placed at the centres of $2 \%$ MEA in $90-\mathrm{mm}$-diameter Petri dishes to determine the radial growth of the cultures. Four Petri dishes for each isolate were incubated in the dark at $5^{\circ} \mathrm{C}$ intervals of each of six temperature regimes ranging from 10 to $35^{\circ} \mathrm{C}$. Isolate growth rates were determined daily after incubation by measuring radial growth (two readings, perpendicular to each other, per plate) using a ruler. The experiment was repeated and data were pooled for the analyses. Data on growth rates were then analysed using a one-way Student's t test at 95\% level of confidence using the SAS JMP IN version 4.0.4., Academic PROCANOVA procedure (Statistical Discovery Software, SAS Institute, $\mathrm{NC}, \mathrm{USA}$ ). Colony colours of the growing cultures at $25^{\circ} \mathrm{C}$ were compared using the mycological colour charts of Rayner (1970).

Table 1. Isolates sequenced in this study and those used in pathogenicity tests and growth studies.

\begin{tabular}{|c|c|c|c|c|c|c|c|c|c|}
\hline \multirow{2}{*}{ 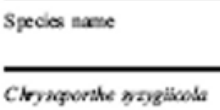 } & \multirow{2}{*}{$\begin{array}{l}\text { bolice number" } \\
\text { CMW299406 }\end{array}$} & \multirow{2}{*}{$\begin{array}{l}\begin{array}{l}\text { Alsenacive } \\
\text { isoince number" }\end{array} \\
\text { CBS124433 }\end{array}$} & \multirow{2}{*}{$\begin{array}{l}\text { Hetanium number } \\
\text { PREMGOZSO }\end{array}$} & \multirow{2}{*}{$\begin{array}{l}\text { Host } \\
\text { S. gainesiet }\end{array}$} & \multirow{2}{*}{$\frac{\text { Otgin }}{\text { Zxilpa }}$} & \multirow{2}{*}{$\begin{array}{l}\text { Callasoe } \\
\text { D. Clangu \& \&. Row }\end{array}$} & \multicolumn{3}{|c|}{ GeiBank accosiba numbers ${ }^{d}$} \\
\hline & & & & & & & FJessoos & FJs05230 & FJ305236 \\
\hline & CMW29941 & CBS124489 & PREM60263 & S. gaineanie & Zanbla & D. Chengu \& I. Roux & F.655006 & FJ305231 & FJ305237 \\
\hline & CMW29942 & CBS124490 & PREMG0288 & S. gaineasie & Zambia & D. Clangu \& 1. Roux & F 1655007 & FJ805232 & Frs05238 \\
\hline \multirow[t]{3}{*}{ Cr. andiends } & CMW2932s" & CBS124503 & PREM60262 & E gronds & Zanba & D. Clangu \& J. Roux & FJ655002 & FJ858709 & Frs05233 \\
\hline & CMW29829 & CBS124512 & PREM60261 & E grondis & Zantia & D. Clengu \& J. Roux & FJ655003 & FJ858750 & F 8305234 \\
\hline & CMW29930 & CBS124502 & PREM60259 & E grondis & Zambla & D. Cleseng \& J. Row & Fj655004 & FJ858711 & Fs30s23s \\
\hline \multirow[t]{4}{*}{ Crr astroupbicasa } & CMW2113 & CBS1 12916 & & E grondis & South Aftion & M. Wiagtield & & & \\
\hline & CMW9327 & CBS1 15843 & & r. grasubas & South Aftion & MJ. Wirfiels & & & \\
\hline & CMW1375 & & & S. gaineasie & Zambia & G. Nakibonge \& f. Roux & & & \\
\hline & CMW13976 & & & E gronds & Zambla & G. Nakaboege \& J. Roux & & & \\
\hline
\end{tabular}

\section{Pathogenicity tests}

The relative pathogenicity of Chrysoporthe spp. strains was determined in inoculation tests on $E$. grandis saplings ( 6 months old) in a greenhouse. Seven isolates, randomly selected among two isolate groups from Zambia and Chr. austroafricana from South Africa and Zambia, were used. For Chr. austroafricana, isolate CMW2113, that has been shown to be highly virulent on Eucalyptus spp. in South Africa (Roux et al. 2003), and two isolates from Syzygium (CMW13975) and Eucalyptus (CMW13976) trees in Zambia, were selected for the study. Prior to inoculation tests, isolates were grown on $2 \% \mathrm{MEA}$ and maintained at $25^{\circ} \mathrm{C}$ under continuous near-fluorescent light for 5 days. 
A total of 160 E. grandis saplings from clone TAG5 with 10-12 mm diameters were acclimatized to greenhouse conditions ( $\sim 13 \mathrm{~h}$ daylight and $\sim 11 \mathrm{~h}$ darkness, approximately $25^{\circ} \mathrm{C}$ ) for 2 weeks. Ten trees were inoculated with each test strain and ten others with a sterile water agar plug to serve as control. A 5-mm-diameter cork borer was used to remove a disc of bark from saplings to expose the cambium, and a mycelial plug of equal size was taken from actively growing cultures and placed into the wounds with the mycelia facing the cambium.

Wounds were sealed with parafilm 'M' (American National Can ${ }^{\mathrm{TM}}$ Chicago, USA) to avoid desiccation. Lesion lengths were recorded 4 weeks after inoculation to determine the pathogenicity of the isolates. Re-isolations were made from lesions and fungi recovered were observed under a light-microscope and identified using conidial characteristics. The experiment was repeated and data were pooled for analyses.

Data were subjected to analyses of variance (ANOVA) using the SAS JMP IN version 4.0.4. Before analysis, arcsine square root transformation of data was made to provide for a normal distribution and stabilised error variance (Sokal and Rohlf 1995) due to heteroscedasticity of variances among samples.

\section{Results}

\section{Collection of samples}

A total of 43 isolates resembling species of Chrysoporthe were collected from Eucalyptus and Syzygium trees in two geographic locations in Zambia. These included 24 isolates each from a separate $E$. grandis tree growing in plantations in Kapweshi and 19 isolates from separate $S$. guineense trees growing in a native forest in Samfya (Fig. 1). Symptoms on Eucalyptus trees included cracking of the bark at the bases of the stems, while isolates from Syzygium trees were obtained from dying branches and stem cankers.

\section{DNA sequencing and phylogenetic analyses}

Amplification products for the DNA regions considered in this study were approximately $519 \mathrm{bp}$ (ITS) and $925 \mathrm{bp}$ ( $\beta$-tubulin) in size. Blast searches for the obtained sequences in the NCBI (www.ncbi.nlm.nih.gov) database confirmed that isolates collected from $E$. grandis and $S$. guineense in Zambia represent species in the Cryphonectriaceae. Isolates showed closest similarity to Chr. austroafricana. All new sequences were deposited in GenBank (Table 1) and their alignment to other species in Chrysoporthe in TreeBase (S279).

A combined sequence dataset, comprising ITS and $\beta$-tubulin gene sequences, produced 1,444 aligned sequence characters of which 1,172 were constant, 83 parsimony uninformative, and 189 parsimony informative. Congruence of the rDNA ITS and $\beta$-tubulin datasets was not supported by the partition homogeneity test (PHT) $(\mathrm{P}=0.03)$. This was most probably due to the highly conserved nature of the rDNA ITS genes of Chrysoporthe spp. (Myburg et al. 2002; Gryzenhout et al. 2004) resulting in poor resolution of the terminal branches. This P-value was less than the conventionally accepted P-value of 0.05 required to combine data. However, several studies have accepted a Pvalue less than 0.05 and have further stated that the conventional $\mathrm{P}$-value of 0.05 is conservative (Cunningham 1997; Darlu and Lecointre 2002; Dettman et al. 2003). Furthermore, similar topology of the phylograms obtained from rDNA ITS and $\beta$-tubulin genes, and the increased bootstrap support for the groups obtained using the combined dataset, suggested that the data of these genes could be considered collectively. Thus, DNA sequence alignments of the rDNA ITS and $\beta$-tubulin gene regions were combined, irrespective of the incongruence of their loci. 
Phylograms obtained by maximum parsimony and NJ analyses were similar and that obtained by NJ was chosen for presentation (Fig. 2). The Chrysoporthe isolates in the phylogram generated from the combined sequence data set resided in eight sub-clades (1-8), clustering separately from the outgroup taxa represented by $C$. parasitica and $C$. japonica [base frequencies: $\pi \mathrm{A}=0.2387, \pi \mathrm{C}=$ $0.2571, \pi \mathrm{G}=0.2660, \pi \mathrm{T}=0.2103$; substitution rates: $\mathrm{A} / \mathrm{C}=1.3649, \mathrm{~A} / \mathrm{G}=1.8944, \mathrm{~A} / \mathrm{T}=1.7195, \mathrm{C} / \mathrm{G}$ $=1.2097, \mathrm{C} / \mathrm{T}=4.4921, \mathrm{G} / \mathrm{T}=1.0000$; proportion of invariable sites $(\mathrm{I})=0.5615$; gamma shape distribution parameter $=0.6928]$. Clades 3-8 represented known isolates of Chrysoporthe that included Chr. austroafricana, Chr. doradensis, Chr. inopina, Chr. cubensis (South America), Chr. cubensis (Asia) and Chrysoporthella hodgesiana. Each clade was strongly supported by bootstrap values of $>80 \%$. New isolates from Zambia (as opposed to the previous isolate from this country in clade 3) resided in clades one and two that were distinct from those representing known species.

Clade 1 represented isolates of 'Chrysoporthe zambiensis' from cankers on the stems of E. grandis and clade 2 represented isolates of ' $C h r$. syzygiicola' from $S$. guineense (100\% bootstrap support). The Chrysoporthe spp. from Zambia residing in clade 1 and 2 were most closely related to Chr. austroafricana (Fig. 2).

The Chrysoporthe isolates comprising the eight clades in the phylogenetic analyses could be distinguished by several different base pairs in the rDNA ITS and $\beta$-tubulin gene regions (Table 2). Twenty-four base pairs were different between Chr. austroafricana and the two new taxa from Zambia. The 'Chr. syzygiicola' isolates from S. guineense in Zambia differed from those of Chr. austroafricana in nine base pairs and from the 'Chr. zambiensis' Isolates from E. grandis in Zambia in five base pairs. The latter species differed from isolates of Chr. austroafricana in ten base pairs (Table 3).

\section{Morphological comparisons}

No teleomorph structures were observed on the specimens from Zambia. Conidiomata of the fungi found on E. grandis (Fig. 3a) and S. guineense (Fig. 3g) in Zambia were generally similar to those for the descriptions of Chrysoporthe spp. (Myburg et al. 2002; Gryzenhout et al. 2004, 2009), being fuscous black to brown and slightly immersed. Conidiomatal necks consisted of textura porrecta. Conidia and conidiophores were similar in size and shape. Various morphological features were, however, distinct from those of the described 'Chr. zambiensis' and 'Chr. syzygiicola'.

The most important features that differentiate the Zambian species from each other and from other Chrysoporthe spp. were conidiomatal shape and conidial tendril colour. Conidiomata of the ' $\mathrm{Chr}$. zambiensis' specimens from E. grandis (Group One) had more globose to ovoid bases with tapering necks and they were rust brown, while conidiomata of the 'Chr. syzygiicola' specimens from $S$. guineense (Group Two) were darker (fuscous black to brown) and had a rostrate shape. These shapes were distinct from those of other Chrysoporthe spp. (Table 4). Conidia of the ' $\mathrm{Chr}$. zambiensis' from E. grandis were also exuded as pale luteous spore tendrils, similar to those of Chr. doradensis, but different from other Chrysoporthe spp. (Table 4).

Cultures of Chr. austroafricana, 'Chr. zambiensis' and 'Chr. syzygiicola' differed in growth rates on $2 \%$ MEA. The optimal temperature for growth was $30^{\circ} \mathrm{C}$ for ' $\mathrm{Chr}$. zambiensis' and 'Chr. syzygiicola', and $25^{\circ} \mathrm{C}$ for Chr. austroafricana. The growth rate of 'Chr. zambiensis' $(6.3 \mathrm{~mm} /$ day $)$ was more rapid than 'Chr. syzygiicola' ( $5.4 \mathrm{~mm} /$ day) with isolates in this group covering the $90-\mathrm{mm}$ plates in 7 days rather than the 8 days for the latter. These were slower growing than $C h r$. austroafricana cultures $(8.0 \mathrm{~mm} /$ day), which covered the same size plates in 5 days (Fig. 5). The differences in growth rates among these isolates of Chrysoporthe were statistically significant $(\mathrm{P}<$ $0.05)$. None of the isolates grew at $10^{\circ} \mathrm{C}$ or $35^{\circ} \mathrm{C}$ on $2 \%$ MEA. 


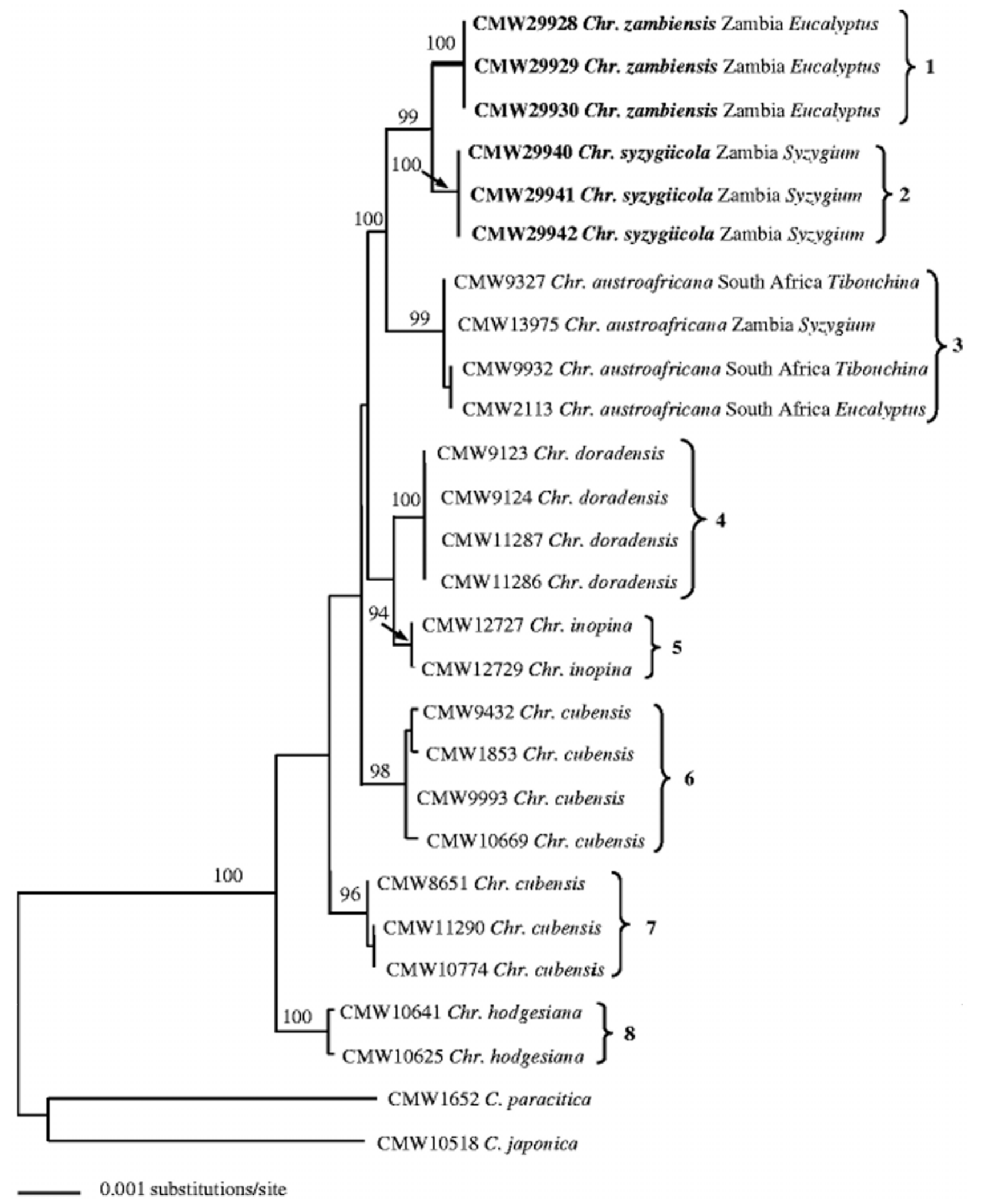

Fig. 2. Neighbour-joining phylogram of the Cryphonectriaceae, indicating the phylogenetic placement of Chrysoporthe zambiensis and Chr. syzygiicola, obtained from distance analysis of combined ITS and $\beta$-tubulin data using the GTR $+\mathrm{I}+\mathrm{G}$ DNA substitution model (gamma shape distribution parameter $=0.6928$ ). Bootstrap values of 1,000 replicates above $80 \%$ are indicated on the branches. Isolates sequenced in this study are in bold. Cryphonectria parasitica and C. japonica sequences were used as outgroup. 
Table 2. Summary of polymorphic nucleotides found within sequences of the ribosomal ITS region and two regions in the $\beta$-tubulin genes for all known Chrysoporthe species, including Chr. zambiensis and Chr. syzygiicola described in this study. Polymorphic nucleotides unique to each species are shown in bold typeface.

\begin{tabular}{|c|c|c|c|c|c|c|c|c|c|c|c|c|c|c|c|c|c|c|c|c|c|c|c|c|c|}
\hline \multirow{2}{*}{\multicolumn{2}{|c|}{ Species }} & \multicolumn{24}{|c|}{ Besorobulin 1 (Bt1a'Be1b) } \\
\hline & & 34 & 127 & $1 \pi$ & 174 & 178 & 179 & 181 & 284 & $\mathbf{2} 1$ & 205 & & 219 & 237 & 239 & 278 & 296 & 347 & 350 & 374 & 401 & & & & \\
\hline \multicolumn{2}{|l|}{ Chropoporate asitroghican } & G & $c$ & c & $\mathrm{c}$ & A & G & $\mathrm{c}$ & $c$ & A & $\mathrm{c}$ & $c$ & c & $\mathrm{c}$ & - & $\mathrm{c}$ & $\mathrm{c}$ & $\mathrm{c}$ & G & $\mathrm{c}$ & $\mathrm{T}$ & & & & \\
\hline \multicolumn{2}{|l|}{ CAr saygibols } & $\mathrm{c}$ & $\mathrm{c}$ & $\mathrm{c}$ & $\mathrm{T}$ & G & G & $\mathrm{c}$ & $\mathrm{c}$ & A & $\mathrm{c}$ & $c$ & c & $\mathrm{c}$ & - & $\mathrm{c}$ & $\mathrm{c}$ & $\mathbf{A}$ & $\mathrm{T}$ & $\mathrm{c}$ & $\mathrm{T}$ & & & & \\
\hline \multicolumn{2}{|l|}{$\mathrm{CAz}$ ambiensis } & c & c & c & $\mathbf{T}$ & $\mathrm{G}$ & G & c & c & A & $\mathrm{c}$ & & c & c & - & c & c & $\mathrm{c}$ & $\mathbf{G}$ & c & A & & & & \\
\hline \multicolumn{2}{|l|}{$C A z$ adensid } & $\mathrm{c}$ & $\mathbf{T}$ & c & $\mathrm{c}$ & G & A & A & A & A & $\mathrm{T}$ & 1 & $\mathbf{T}$ & $\mathrm{T}$ & - & $\mathbf{T}$ & $\mathbf{T}$ & $\mathrm{c}$ & $\mathbf{G}$ & c & $\mathrm{T}$ & & & & \\
\hline \multicolumn{2}{|l|}{$C A x$ calvesibs } & $\mathrm{c}$ & $\mathrm{c}$ & $\mathrm{c}$ & $\mathrm{c}$ & G & $\mathbf{G}$ & A & A & A & $\mathrm{T}$ & 1 & $\mathrm{~T}$ & $\mathrm{~T}$ & - & $\mathrm{T}$ & $\mathrm{c}$ & $\mathrm{c}$ & G & c & $\mathrm{T}$ & & & & \\
\hline \multicolumn{2}{|l|}{$C A z$ dradenjis } & $\mathrm{c}$ & $\mathrm{c}$ & $T$ & $\mathrm{c}$ & A & G & A & A & A & $\mathrm{T}$ & & c & c & $\cdot$ & $\mathrm{T}$ & $\mathrm{c}$ & $\mathrm{c}$ & G & A & $\mathrm{T}$ & & & & \\
\hline \multicolumn{2}{|l|}{ CAr incopina } & $\mathrm{c}$ & $\mathrm{c}$ & $\mathrm{c}$ & $\mathrm{c}$ & G & G & A & $A$ & A & $\mathrm{T}$ & & c & $\mathrm{c}$ & $\mathrm{T}$ & $\mathrm{c}$ & $\mathrm{c}$ & $\mathrm{c}$ & G & c & $\mathrm{T}$ & & & & \\
\hline \multicolumn{2}{|l|}{ Chrogoporate hodgesiana } & $\mathrm{c}$ & $\mathrm{c}$ & $\mathrm{c}$ & $\mathrm{c}$ & $\mathrm{G}$ & G & A & A & G & $\mathrm{T}$ & & $\mathbf{T}$ & $\mathrm{T}$ & $\cdot$ & $\mathrm{c}$ & $\mathrm{T}$ & $\mathrm{c}$ & $\mathbf{G}$ & c & $\mathrm{T}$ & & & & \\
\hline \multirow[t]{2}{*}{ Species } & ns & $15.8 \mathrm{~s}$ & $\mathrm{rrs2}$ & & & & & & & & \multicolumn{15}{|c|}{ Betrobulin 2 (BC2a' BC2b) } \\
\hline & 88 & 118 & 151 & 350 & 403 & 411 & 429 & 436 & 40 & $50 s$ & 80 & 97 & 105 & 148 & 149 & 203 & 209 & 238 & 343 & 269 & 353 & 374 & 383 & 422 & $4: 4$ \\
\hline $\begin{array}{l}\text { Chrosoporthe } \\
\text { awatrapticiona }\end{array}$ & $\cdot$ & A & $\mathrm{c}$ & c & $\cdot$ & $\mathrm{T}$ & A & A & $\mathrm{c}$ & G & $\mathrm{T}$ & G & c & $\mathbf{T}$ & G & c & $\mathrm{c}$ & G & c & $\mathbf{A}$ & c & $\mathrm{T}$ & $\mathrm{c}$ & G & $\mathrm{c}$ \\
\hline CAz syrgilimals & - & A & $\mathrm{c}$ & - & $\cdot$ & c & A & A & c & G & $\mathbf{T}$ & G & c & $\mathrm{T}$ & $\mathbf{G}$ & c & $\mathbf{A}$ & G & G & A & c & $\mathrm{T}$ & c & G & $c$ \\
\hline Che somblensb & $\cdot$ & A & $\mathrm{c}$ & $\cdot$ & $\cdot$ & C & A & A & A & G & $\mathbf{T}$ & G & c & $\mathrm{T}$ & G & A & A & G & G & A & c & $\mathbf{T}$ & $\mathrm{c}$ & $\mathbf{G}$ & c \\
\hline$C A z$ calonsit & - & A & $\mathbf{T}$ & - & - & $\mathrm{c}$ & A & A & $\mathrm{c}$ & G & $\mathrm{c}$ & G & $\mathrm{c}$ & $\mathrm{T}$ & $G$ & $\mathrm{c}$ & $\mathrm{c}$ & G & G & A & $\mathrm{c}$ & $\mathbf{T}$ & $\mathrm{c}$ & G & A \\
\hline$C A x$ calvensis' & - & $\mathbf{A}$ & $\mathrm{c}$ & - & $\mathrm{T}$ & $\mathrm{T}$ & G & G & $\mathrm{c}$ & $A$ & $\mathrm{c}$ & G & $\mathrm{c}$ & $\mathrm{c}$ & G & $\mathrm{c}$ & $\mathrm{c}$ & $T$ & G & A & $\mathrm{T}$ & $\mathrm{T}$ & $\mathrm{T}$ & G & $\mathrm{c}$ \\
\hline$C A z$ dradesib & $\mathbf{T}$ & $A$ & $\mathrm{c}$ & - & $\cdot$ & $\mathrm{c}$ & A & A & $\mathrm{c}$ & G & $\mathrm{c}$ & G & $\mathrm{T}$ & $\mathrm{c}$ & G & $\mathrm{c}$ & $\mathbf{T}$ & G & $\mathbf{G}$ & G & $\mathbf{T}$ & $\mathbf{T}$ & $\mathrm{c}$ & G & $\mathrm{c}$ \\
\hline$C A z$ incogina & - & G & $\mathrm{c}$ & - & - & $\mathrm{c}$ & A & G & $\mathrm{c}$ & G & $\mathrm{c}$ & G & $\mathrm{T}$ & $\mathrm{c}$ & $\mathbf{A}$ & $\mathrm{c}$ & $\mathbf{T}$ & $\mathbf{G}$ & $\mathbf{G}$ & A & $\mathrm{T}$ & $\mathbf{T}$ & $\mathrm{c}$ & $\mathbf{G}$ & $\mathrm{c}$ \\
\hline $\begin{array}{l}\text { Chrogoponthe } \\
\text { hodgeoiasa }\end{array}$ & $\cdot$ & $\mathbf{G}$ & $\mathrm{c}$ & - & - & $\mathrm{c}$ & A & G & $\mathrm{c}$ & $\mathrm{G}$ & $\mathrm{c}$ & A & c & $\mathbf{T}$ & $\mathrm{G}$ & $\mathrm{c}$ & $\mathrm{c}$ & $\mathbf{G}$ & G & A & c & $\mathrm{c}$ & $c$ & A & $c$ \\
\hline
\end{tabular}

Table 3. Number of fixed DNA base pairs between different phylogenetic groups of Chr. austroafricana, Chr. syzygiicola and Chr. zambiensis.

\begin{tabular}{|c|c|c|}
\hline Groups & Chysopovite zambiessis & Oryseganthe syzgilleab \\
\hline Orysonovite awstrogbsena & 10 & 9 \\
\hline Drysopovite soyglenala & 5 & \\
\hline
\end{tabular}

Table 4. Comparison of Chrysoporthe zambiensis and Chrysoporthe syzygiicola with other Chrysoporthe species.

\begin{tabular}{|c|c|c|c|c|c|c|c|c|c|c|c|}
\hline Spocies & $\begin{array}{l}\text { Pxhogeniciny } \\
\text { co } \\
\text { Euculypsts }\end{array}$ & $\begin{array}{l}\text { Optimal } \\
\text { conpe foe } \\
\text { growh }\end{array}$ & $\begin{array}{l}\text { Goweth rxe } \\
\infty \mathrm{MEA} \\
\text { menld }\end{array}$ & $\begin{array}{l}\text { Cooidionusa } \\
\text { base with } \\
\text { (um) }\end{array}$ & $\begin{array}{l}\text { Coesiodiomata } \\
\text { shape }\end{array}$ & $\begin{array}{l}\text { Max. } \\
\text { seck } \\
\text { leght } \\
(\mu \mathrm{m})\end{array}$ & Telosemongh & $\begin{array}{l}\text { Cooiding } \\
\text { shape }\end{array}$ & $\begin{array}{l}\text { Coeidirm size } \\
(\mu \mathrm{m})\end{array}$ & $\begin{array}{l}\text { Spoct } \\
\text { mass }\end{array}$ & Referesce \\
\hline $\mathrm{Ch}$ asuraghicase & High" & $25-30^{\circ} \mathrm{C}$ & 8.0 & $90-120$ & $\begin{array}{l}\text { Pyriferm so } \\
\text { pulvinure }\end{array}$ & 200 & Ksown & $\begin{array}{l}\text { Obloeg } 10 \\
\text { ovoud }\end{array}$ & $3-4(-4.5) \times 1.5-2$ & Bright yellow & $\begin{array}{l}\text { This stady; } \\
\text { Gryzenbou: } \\
\text { a al. } 2004\end{array}$ \\
\hline Chv.9agilicale & Very hight & $30^{\circ} \mathrm{C}$ & 5.4 & $250-500$ & $\begin{array}{l}\text { Ovoid wizh } \\
\text { apering sedk }\end{array}$ & 220 & Unknown & Obloeg & $\begin{array}{c}2.1-) 2.5-3.5(-4.0) \\
\times(1.2 .) 4.5-20\end{array}$ & Bright yellow & This stady \\
\hline Chy. sambiensis & Low & $30^{\circ} \mathrm{C}$ & 6.3 & $208-310$ & $\begin{array}{l}\text { Pyriform to } \\
\text { roestaxe }\end{array}$ & 300 & Unknown & Obloeg & $\begin{array}{c}(2.5-) 3.0-3.5(-4.0) \\
\times(1.1-) 15-20\end{array}$ & Pale croan & This stady \\
\hline Chr dovadensis & Low" & $30^{\circ} \mathrm{C}$ & - & $100-290$ & $\begin{array}{l}\text { Pyriform so } \\
\text { pulvinue }\end{array}$ & 300 & Ksown & $\begin{array}{l}\text { Obloog } 10 \\
\text { onoid so } \\
\text { cyliedrioal }\end{array}$ & $\begin{array}{l}(3-) 35-5(-6.5) \\
\times 15-2(-2.5)\end{array}$ & Pale croam & $\begin{array}{l}\text { Gryenboes } \\
\text { \& al. } 2005\end{array}$ \\
\hline $\mathrm{Cl}$ s inopothe & Unknow: & $25^{\circ} \mathrm{C}$ & . & $70-710$ & $\begin{array}{l}\text { Subalase so } \\
\text { pyrifoem to } \\
\text { palvinure }\end{array}$ & 790 & Known & Obloeg & $\begin{array}{l}(3-) 3.5-4 \times(1.5-) \\
2-2.5\end{array}$ & Brighe yellow & $\begin{array}{l}\text { Gryzenboes } \\
\text { \& al. } 20006\end{array}$ \\
\hline Chr hadgeriena & Low" & $25^{\circ} \mathrm{C}$ & - & $145-635$ & $\begin{array}{l}\text { Pulvinate, } \\
\text { coasioeally } \\
\text { pyrifoem }\end{array}$ & 390 & Uaknowa & Obloeg & $\begin{array}{l}\text { (3-) } 3.5-5(-5.5)^{x} \\
\text { is }-2(-2.5)\end{array}$ & Bright yellow & $\begin{array}{l}\text { Wiagfidd } \\
\text { \& al. } 2001 ; \\
\text { Gryzenboz: } \\
\text { a al. } 2004\end{array}$ \\
\hline Chr cubessis & Low & $30^{\circ} \mathrm{C}$ & . & $100-950$ & $\begin{array}{l}\text { Pyrifoen so } \\
\text { palvinure }\end{array}$ & 230 & Konew & Obloog & (3-) $3.5 \times 4.5(-5)$ & Brigh yellow & $\begin{array}{l}\text { Roux et al. } \\
20003 \\
\text { Gryzenboes } \\
\text { \& al. } 2004\end{array}$ \\
\hline
\end{tabular}

In the greenbouse

" $\mathrm{b}$ the feld, species described in this stody $x e$ in bold 

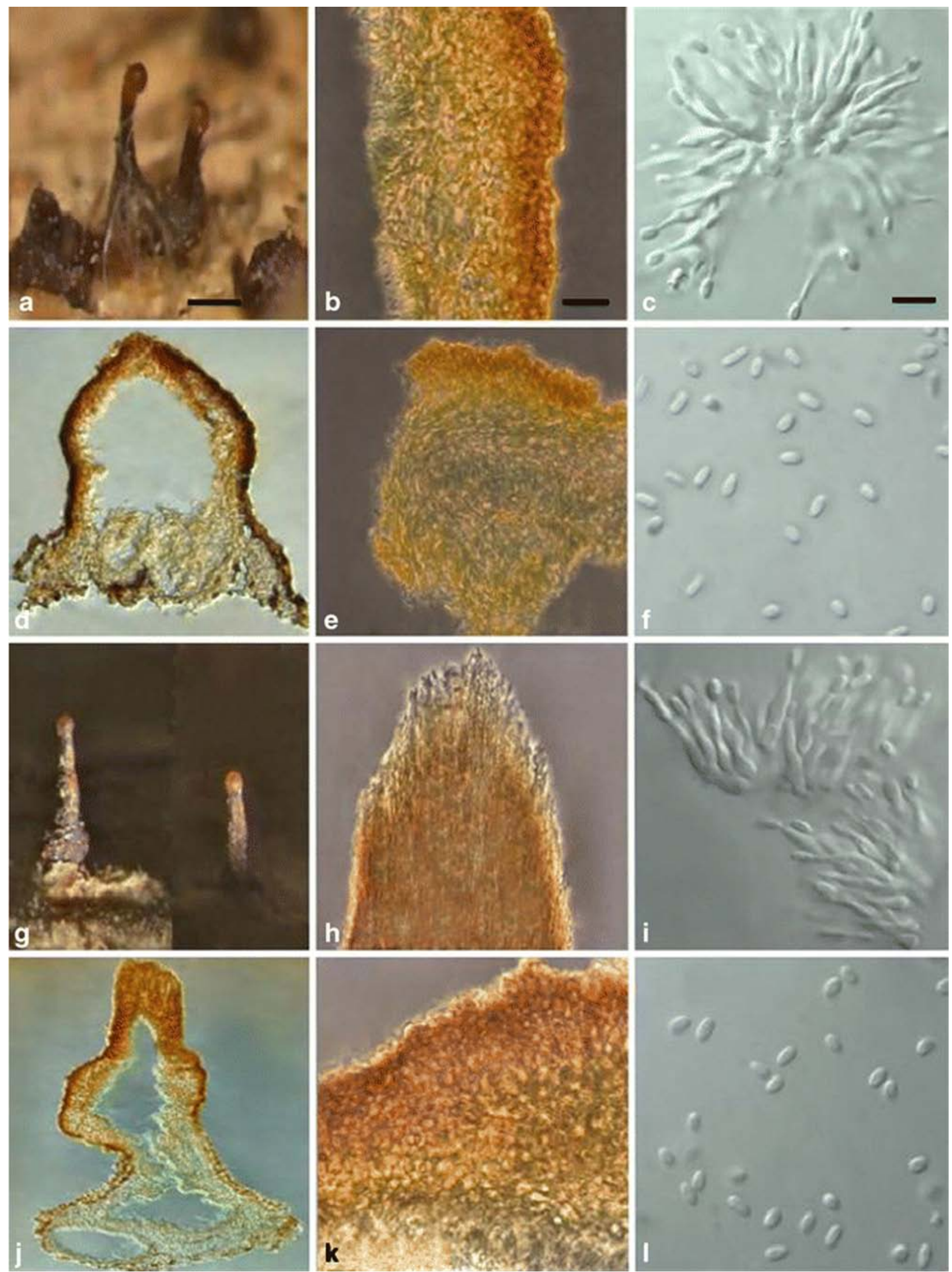

Fig. 3. Fruiting structures of a-f Chrysoporthe zambiensis. a Conidiomata on bark. b Tissue of conidiomatal neck. $\mathbf{c}$ Conidiophores with attached conidiogenous cells. d Longitudinal section through conidiomata. e Tissue of conidiomatal base. f Conidia. g-l Chrysoporthe syzygiicola. $g$ Conidiomata on bark. $\mathbf{h}$ Tissue of conidiomatal neck. i Conidiophores with attached conidiogenous cells. $\mathbf{j}$ Longitudinal section through conidiomata. $\mathbf{k}$ Tissue of conidiomatal base. I Conidia. Scale 


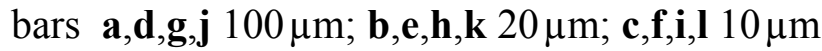

\section{Taxonomy}

Morphological characteristics and phylogenetic data provided good evidence that the fungi from $E$. grandis and $S$. guineense in Zambia represent undescribed species of Chrysoporthe. These species were distinct in culture, having growth rates that were significantly different from their closest relative, Chr. austroafricana. Conidiomatal shape and tendril colour were also different from those of other species of Chrysoporthe. Phylogenetic analyses revealed significant differences in DNA sequence data for the isolates from Zambia, compared to the described species of Chrysoporthe. Two new species are thus described to accommodate the isolates from Zambia.

Specimens linked to the descriptions of the two new species have only anamorph structures. Based on DNA sequence data and morphology they have, however, been firmly established as two species of Chrysoporthe. In the absence of a teleomorph, the anamorph genus Chrysoporthella, described for Chrysoporthella hodgesiana (Gryzenhout et al. 2004), would be appropriate to accommodate the Zambian species. However, the name Chrysoporthella hodgesiana has caused considerable confusion where scientists have failed to appreciate the connection of this species to Chrysoporthe, or have mistakenly believed that this species is the anamorph of Chr. cubensis. As Chrysoporthe is a recently established genus (Gryzenhout et al. 2004), and includes only five species (Gryzenhout et al. 2009), application of a formal anamorphic genus is confusing and unnecessary, even where only anamorph structures are found. For the same reason, no anamorph genera have been established for other recently described genera in the Cryphonectriaceae (Gryzenhout et al. 2009).

In the absence of the teleomorph, Recommendation 59A.3 of the International Code of Botanical Nomenclature (McNeill et al. 2007) is followed. Here, it is stated that the description of an anamorph name of the holomorph is unnecessary if it is proven that the anamorph structures represent the holomorph, and there is no functional need for a second name. The Code also states, in Art. 59.7, that if teleomorph structures are found at a later stage, the teleomorph structures can be epitypified to the existing name that was based on anamorph structures, to preserve its status. We, therefore, describe the two species from Zambia in Chrysoporthe, even though sexual structures are not present.

Chrysoporthe zambiensis Chungu, Gryzenh. \& Jol. Roux, sp. nov. Figs. 3a-f \& 4a, MycoBank MB509677.

Description: Conidiomata ferruginea rostrata globosa. Conidia oblonga. Massulae sporarum laete luteae. Culturae albae maculis cinnamomeis, ad $6.3 \mathrm{~mm} /$ day in temperatura optima $30^{\circ} \mathrm{C}$ crescentes.

Conidiomata slightly immersed, rust brown, rostrate, globose, of Chrysoporthella-type, conidiomatal bases above the bark surface 110-240 $\mu \mathrm{m}$ high, 208-310 $\mu \mathrm{m}$ wide with necks 250-300 $\mu \mathrm{m}$. Conidiomatal locules are uniloculate with convoluted inner surfaces, locules 150-285 $\mu \mathrm{m}$ diameter (Fig. 3a, d). Neck tissue of textura porrecta (Fig. 3b), base tissue of textura globulosa, the outer cells with thickened walls (Fig. 3e). Conidiophores hyaline, with basal cells of irregular shape, $(2.2-) 3.0-4.5(-6.5) \times(1.1-) 2.0-2.0(-3.5) \mu \mathrm{m}, 95 \%$ confidence intervals $=3.91-4.44 \times 2.50-2.94$ $\mu \mathrm{m}$, branched irregularly at the bases or above into cylindrical cells with or without separating septa, total length of conidiophores $(14.2-) 15.2-16.0(-17.5) \mu \mathrm{m}, 95 \%$ confidence intervals $=$ 13.79-16.02 $\mu \mathrm{m}$ (Fig. 3c). Conidiogenous cells phialidic, apical or lateral on branches beneath a septum, cylindrical with or without attenuated apices, $(1.2-) 2.0-3.5(-5.4) \mu \mathrm{m}$ wide, $95 \%$ confidence intervals $=3.01-3.43 \mu \mathrm{m}$ wide (Fig. 3c). Conidia hyaline, non-septate, oblong, $(2.5-) 3.0-3.5(-4.0) \times(1.1-) 1.5-2.0 \mu \mathrm{m}, 95 \%$ confidence intervals $=3.17-3.23 \times 1.58-1.62 \mu \mathrm{m}$ (Fig. 3f). Spore masses pale luteous (cream). 

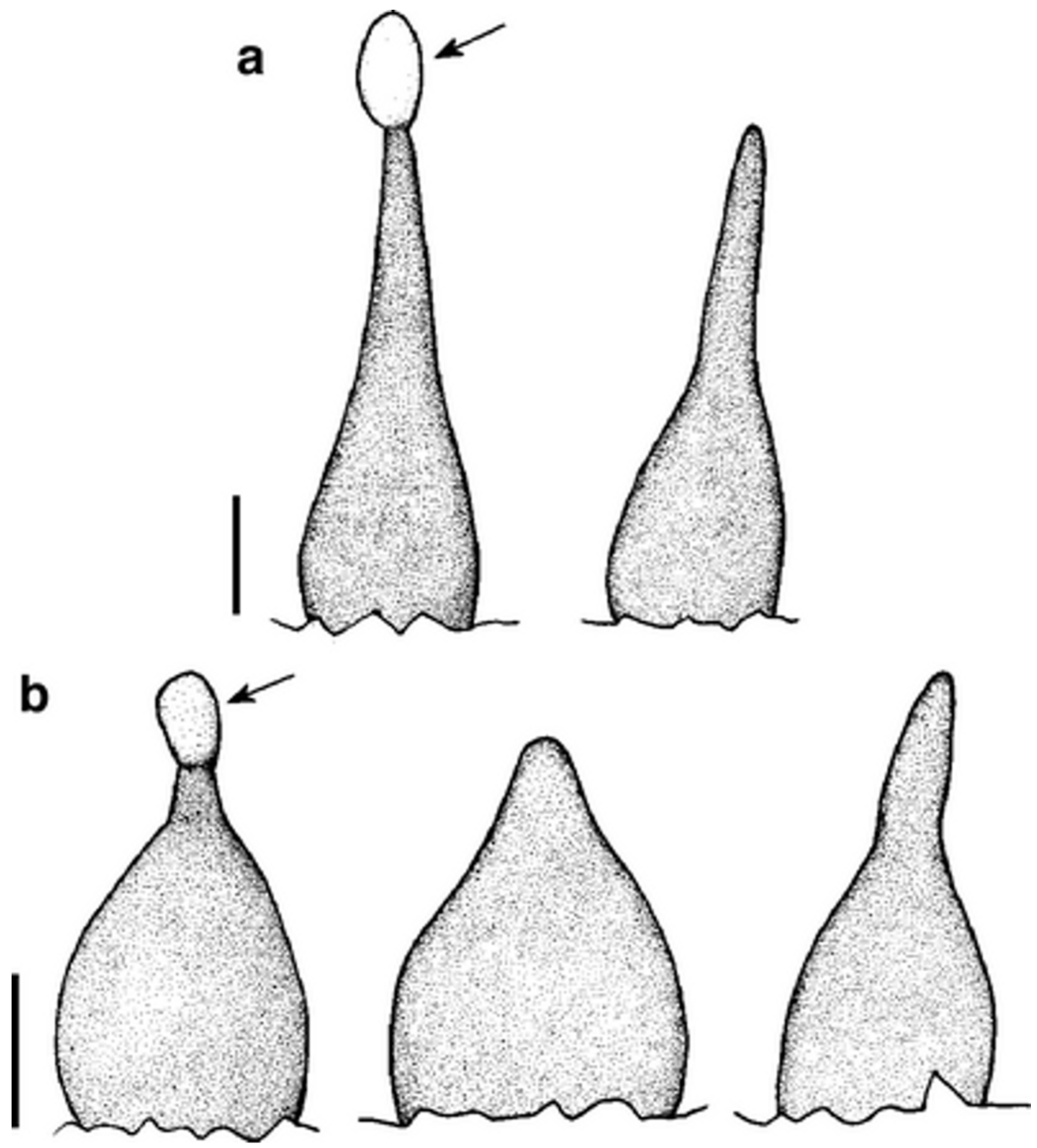

Fig. 4. Schematic drawings of diagnostic characteristics of: a Chrysoporthe zambiensis and b Chrysoporthe syzygiicola conidiomata (spore drops indicated with arrows). Scale bars $100 \mu \mathrm{m}$.

Etymology: Name refers to Zambia, the country where the fungus was first collected.

Teleomorph: Not seen.

Culture characteristics: On MEA, Chr. zambiensis cultures white with cinnamon patches, fluffy with a smooth margin, growing fast at the rate of $6.3 \mathrm{~mm} /$ day at $30^{\circ} \mathrm{C}$ optimal temperature covering a 90-mm plate in 7 days (Fig. 5). Chrysoporthe zambiensis does not sporulate in culture after subculturing and does not produce teleomorph structures in culture.

Substrate: Stems of Eucalyptus grandis trees. 
Distribution: Kapweshi, Luapula Province, Zambia.

Specimens examined: ZAMBIA, Luapula Province, Kapweshi, on stems of Eucalyptus grandis, collected August 2008, D. Chungu \& J. Roux, holotype PREM60262, living ex-type culture CMW29928/CBS124503, paratype PREM60261 and PREM60259, living ex-paratype cultures CMW29929/CBS124512 and CMW29930/CBS124502.

Chrysoporthe syzygiicola Chungu, Gryzenh. \& Jol. Roux sp. nov.

Figs. 3g-1 \& 4b, MycoBank MB509660

Distribution: Conidiomata globosa fusco-nigra vel brunnea. Conidia oblonga vel ovoidea. Massulae sporarum vivide flavissimae vel luteae. Culturae albae medio maculis umbrinis vel avellaneis, ad $5.4 \mathrm{~mm} /$ day in temperatura optima $30^{\circ} \mathrm{C}$ crescentes.

Conidiomata slightly immersed in bark, globose, fuscous-black to brown, of Chrysoporthella-type,, conidiomatal bases above the bark surface 197-234 $\mu \mathrm{m}$ high, 250-500 $\mu$ m wide with necks 150 $220 \mu \mathrm{m}$ long. Conidiomata uniloculate, locules 290-361 $\mu \mathrm{m}$ diameter with convoluted inner surfaces (Fig. 3g, j). Neck tissue of textura porrecta (Fig. 3h), basal tissue of textura globulosa, the outer cells with thickened walls (Fig. 3k). Conidiophores hyaline, with basal cells of irregular shape, $(2.0-) 3.0-5(-7.5) \times(1.3-) 2.5-3.0(-4.5) \mu \mathrm{m}, 95 \%$ confidence intervals $=4.51-4.89 \times 2.80-$ $3.11 \mu \mathrm{m}$, branched irregularly at the bases or above into cylindrical cells with or without separating septa, total lengths of conidiophores (10.9-)11.1-12.9(-13.7) $\mu \mathrm{m}, 95 \%$ confidence intervals $=$ $11.90-12.51 \mu \mathrm{m}$ (Fig. 3i). Conidiogenous cells phialidic, apical or lateral on branches beneath a septum, cylindrical shape with or without attenuated apices, $(1.4-) 1.8-2.9(-4.5) \mu \mathrm{m}$ wide, $95 \%$ confidence intervals $=2.62-2.99 \mu \mathrm{m}$ wide, collarettes and periclinal thickenings inconspicuous (Fig. $3 i)$. Conidia hyaline, non-septate, oblong to ovoid $(2.0-) 2.5-3.5(-4.0) \times(1.2-) 1.5-2.0 \mu \mathrm{m}, 95 \%$ confidence intervals $=3.08-3.12 \times 1.68-1.72 \mu \mathrm{m}$ (Fig. 31$)$. Spore masses bright yellow luteous.

Etymology: Name refers to the Syzygium trees hosting this fungus, where cola means dweller in Latin.

Teleomorph: Not seen.

Culture characteristics: On MEA, Chr. syzygiicola cultures white with umber to hazel patches in the middle, fluffy with a smooth margin, growing fast at the rate of $5.4 \mathrm{~mm} /$ day at $30^{\circ} \mathrm{C}$ optimal temperature covering a $90-\mathrm{mm}$ plate in 8 days. Chrysoporthe syzygiicola does not sporulate in culture after sub-culturing and does not produce teleomorph structures in culture.

Substrate: Stems of Syzygium guineense.

Distribution: Samfya, Luapula Province, Zambia.

Specimens examined: ZAMBIA, Luapula Province, Samfya, on stem of Syzygium guinense, collected August 2008, D. Chungu \& J. Roux, holotype PREM60260, living ex-type culture CMW29940/CBS124488, paratype PREM60263 and PREM60258, living ex-paratype cultures CMW29941/CBS124489 and CMW29942/CBS124490.

Chrysoporthe hodgesiana (Gryzenh. \& M.J. Wingf.) Chungu, Gryzenh. \& M.J. Wingf. comb. nov. MycoBank MB515496

Basionym: Chrysoporthella hodgesiana Gryzenh. \& M.J. Wingf. Studies in Mycology 50: 135-136.

Notes: For reasons stated above, the name Chrysoporthella hodgesiana is confusing in a small and 
well-known genus such as Chrysoporthe. There is also no practical need to refer to this species using a name other than Chrysoporthe, because the holomorph of the fungus is well established. We, therefore, propose that the species should be renamed as Chrysoporthe hodgesiana (Gryzenh. \& M.J. Wingf.) Chungu, Gryzenh. \& M.J. Wingf. to encourage the use of a one name system for Chrysoporthe.

\section{Pathogenicity tests}

Cambial lesions, as well as external bark discolouration, were found on all inoculated Eucalyptus saplings at the time of data collection. No lesions developed in any of the control inoculations. The analyses of variance revealed significant differences between strains of the Chrysoporthe spp. $(\mathrm{P}<$ 0.001) (Fig. 5). The most pathogenic isolates were those of Chr. syzygiicola (Group Two), which produced average lesion lengths of $160 \mathrm{~mm}$. Chr. zambiensis (Group One) produced average lesions lengths of $60.5 \mathrm{~mm}$. The three isolates of Chr. austroafricana showed considerable variation in lesion length, with CMW2113 more pathogenic $(110 \mathrm{~mm})$ than CMW13975 $(78 \mathrm{~mm})$. The shortest lesions $(9.55 \mathrm{~mm})$, that were not significantly different from the controls, were produced by $C h r$. austroafricana isolate CMW13976 from Zambia. Chrysoporthe zambiensis and Chr. syzygiicola were consistently isolated from lesions on inoculated trees, confirming that they were the cause of the lesions, while no Chrysoporthe spp. were obtained from the control inoculations.

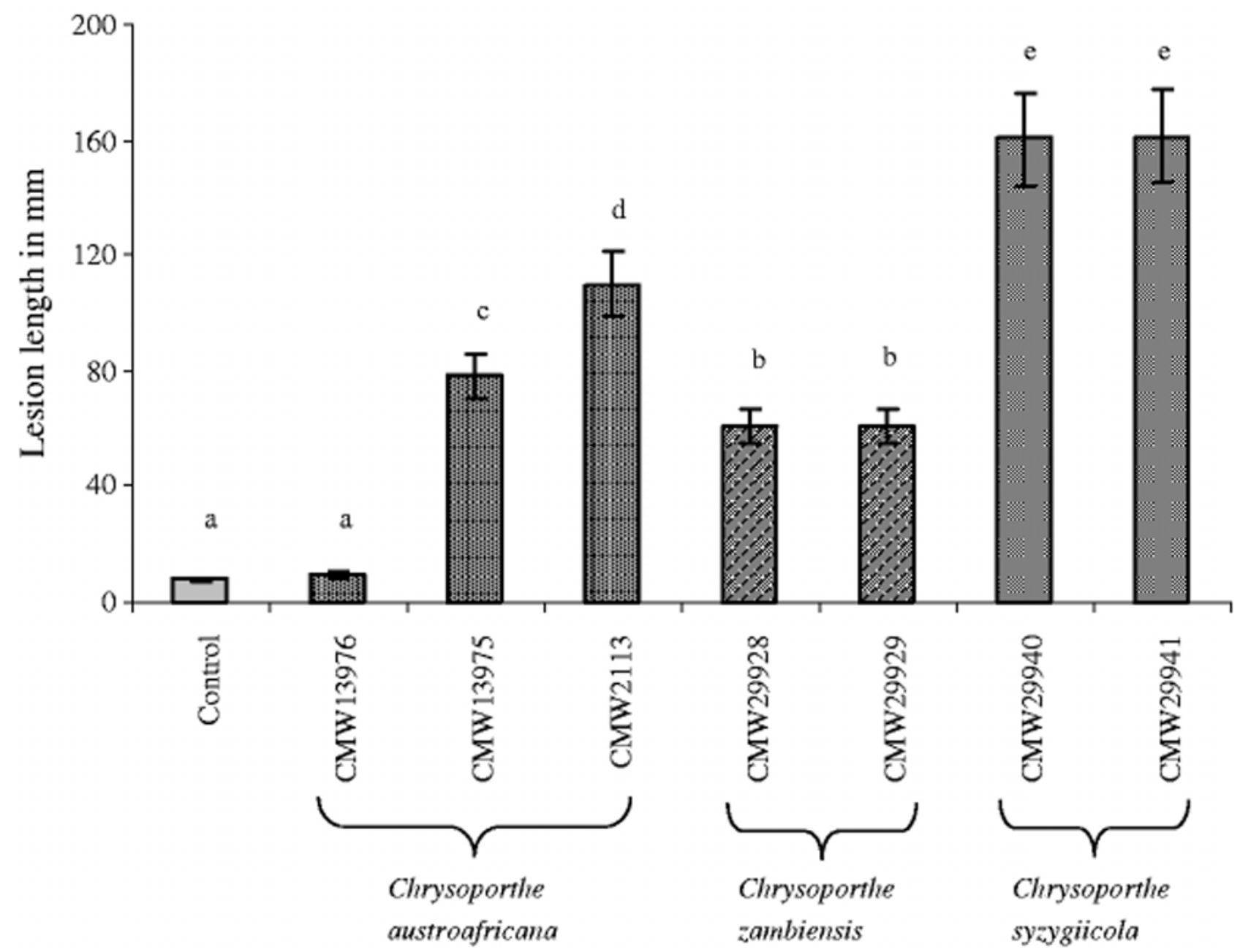

Strains of Chrysoporthe species

Fig. 5. Lesion lengths in mm associated with inoculations of isolates of Chrysoporthe austroafricana (CMW13976, CMW13975, CMW2113), Chrysoporthe zambiensis (CMW29928, CMW29929) and Chrysoporthe syzygiicola (CMW29940, CMW29941) on a Eucalyptus grandis clone in the greenhouse after 4 weeks. A total of 160 lesion lengths were measured. Different letters 
above the bars indicate significant differences in the pathogenicity of the Chrysoporthe strains $(\mathrm{P}<$ 0.001); error bars indicate the standard error of the means.

\section{Discussion}

In this study, we have shown that unknown isolates of Chrysoporthe obtained from E. grandis and $\mathrm{S}$. guineense in Zambia represent two undescribed species, different from other Chrysoporthe spp. The description of these new taxa as Chr. zambiensis and Chr. syzygiicola is supported by morphological characteristics and DNA sequence data. These species were both shown to be pathogenic to the Eucalyptus clone tested in the greenhouse, with $\mathrm{Chr}$. syzygiicola being highly pathogenic.

The two newly described Chrysoporthe spp. from Zambia have morphological characteristics typical of Chrysoporthe. Chrysoporthe zambiensis and Chr. syzygiicola have fuscous black to rust brown conidiomata that are slightly immersed. Similarities also exist in the tissue of the conidiomatal necks and bases that were similar to those in previous descriptions of Chrysoporthe spp. No statistical differences were observed in the conidial sizes or shapes of these species from other Chrysoporthe spp. (Gryzenhout et al. 2009), all producing oblong, hyaline and non-septate conidia.

Based on phylogenetic analyses and morphology, Chr. zambiensis and Chr. syzygiicola are most closely related to Chr. austroafricana. Chrysoporthe austroafricana is common in southern Africa and has previously also been reported from Zambia (Nakabonge et al. 2006). However, conidiomata of Chr. zambiensis had more globose to ovoid bases with tapering necks and were rust brown, while conidiomata of Chr. syzygiicola were darker and had a more rostrate shape. These shapes were distinct from other Chrysoporthe spp., including Chr. austroafricana. Furthermore, Chr. syzygiicola has conidia that are expelled as pale luteous spore drops while Chr. austroafricana and Chr. zambiensis produced bright yellow spore masses. Chrysoporthe zambiensis and Chr. syzygiicola also differ from Chr. austroafricana in their higher optimal growth temperatures at $30^{\circ} \mathrm{C}$, compared to that of Chr. austroafricana $\left(25^{\circ} \mathrm{C}\right)$.

In this study, we report on two new species of Chrysoporthe for which only the anamorph is known. This is similar to Chrysoporthella hodgesiana, which was described in a new anamorph genus because no sexual structures were known for it (Gryzenhout et al. 2004). The absence of sexual structures would normally have required that the two species from Zambia be described in the anamorphic genus Chrysoporthella. However, use of two names for Chrysoporthe spp., where some species have the anamorph name and others the teleomorph name, would have been extremely confusing, and we therefore chose to describe these fungi in Chrysoporthe. For the same reason, the new combination Chrysoporthe hodgesiana has been provided in an attempt to establish a more uniform and logical taxonomy for this genus.

Symptoms on Eucalyptus trees from which Chr. zambiensis was collected were characterised by swelling cankers and cracking at tree bases. Both Chr. zambiensis and Chr. syzygiicola produced significant lesions on 6-month-old trees inoculated in a greenhouse, with some trees inoculated with Chr. syzygiicola starting to die after 4 weeks. Although Chr. syzygiicola was found only on Syzygium trees, our findings clearly show that this is a potentially important pathogen of Eucalyptus spp. Nonetheless, the pathogenicity tests for Chr. syzygiicola and Chr. zambiensis on S. guineense were not investigated due to unavailability in South Africa of this native Zambian tree species. Such tests, which are needed in future, would have provided valuable information relating to the importance of these fungi to the natural environment of Zambia. 
The relative susceptibility of Eucalyptus spp. to stem canker disease induced by different Chrysoporthe spp. has been shown in a number of studies in which Chr. austroafricana, Chr. cubensis, Chr. doradensis and Chr. hodgesiana were used to inoculate trees (Table 4). Following inoculation, Chr. austroafricana from South Africa was shown to be the most pathogenic species (Roux et al. 2003; Wingfield 2003; Rodas et al. 2005; Gryzenhout et al. 2005). Results of the present study have, however, shown that Chr. zambiensis and Chr. syzygiicola are more pathogenic on Eucalyptus than both isolates of Chr. austroafricana from Zambia and South Africa, including isolate CMW 2113 from South Africa that has been selected for its high level of pathogenicity and which was included in previous studies (Roux et al. 2003; Rodas et al. 2005). This suggests that Chr. syzygiicola and Chr. zambiensis are more pathogenic than Chr. austroafricana and that both species, particularly Chr. syzygiicola because of significantly greater lesions induced in this study, should be considered as potentially important pathogens of Eucalyptus in the region.

Non-native Eucalyptus plantations in Zambia are often established in proximity of closely related native tree species in the Myrtales (Chidumayo 1997; Chipeta 1999). In such cases, pathogens of either these related hosts could cause cross-infection that may result in serious disease outbreaks (Slippers et al. 2005). Chrysoporthe austroafricana in South Africa was first found on introduced Eucalyptus spp. and only years later on native Syzygium sp., considered as a native host (Heath et al. 2006). Because pathogenic fungi and related diseases of native trees in Zambia have been less studied, and diseases of Eucalyptus plantations have only recently received attention (Shakachite 1991; Roux et al. 2005; Muimba-Kankolongo et al. 2009), threats from these fungi for closely related non-native trees deserve further investigations.

Introduced pathogens can infect and cause considerable damage to native trees. Examples of this include chestnut blight caused by C. parasitica (Anagnostakis 1987; Heiniger and Rigling 1994), and Dutch Elm Disease caused by Ophiostoma ulmi and O. novo-ulmi (Sinclair and Lyon 2005). Similarly, Chr. syzygiicola and Chr. zambiensis could be destructive if introduced into other countries or continents where Eucalyptus or other related and susceptible trees grow as natives. In this regard, countries such as Australia, with large numbers of native Eucalyptus spp., and countries with native trees also possibly susceptible, such as those in South and Central America with high diversities of native Melastomataceae, should be particularly concerned regarding the possible spread of these pathogens. Similarly, Chrysoporthe spp. present in Zambia might pose an important threat to the biodiversity of other countries in Africa with native Myrtaceae or Eucalyptus plantations.

Results of this study have important implications for Eucalyptus plantation forestry in Zambia and in the sub-region. Tree breeding programmes should take Chr. zambiensis and Chr syzygiicola into consideration to ensure eucalypts that are selected for plantation development are not susceptible to infection by these fungi. Likewise, Chr. austroafricana that is also present in Zambia and in other countries in southern Africa should be part of assessments for resistance in breeding programmes. Furthermore, Chr. cubensis that occurs in the Democratic Republic of Congo, Malawi and Mozambique (Roux et al. 2003; Nakabonge et al. 2006) has the potential to cause significant damage to Eucalyptus forestry in Zambia and other countries of the sub-region.

\section{Acknowledgments}

We acknowledge the assistance from Copperbelt Forestry Company (CFC), Zambia Forests and Forestry Industrial Corporation (ZAFFICO) and Zambian Forestry Department during collection of samples. Joha Grobbelaar and Pieter de Meyer are thanked for field assistance during the survey. Drs. Amy Rossman (BPI, USDA), David Hawksworth (Universidad Complutense de Madrid, Spain; Natural History Museum, London) and Walter Gams are thanked for advice on the use of Chrysoporthella and Article 59. We thank Dr. Hugh Glen for Latin translations. This study was in 
part funded by the National Research Foundation (NRF) of South Africa through a grant for a collaborative research programme between FABI at University of Pretoria (South Africa) and School of Natural Resources at Copperbelt University (Zambia), and a scholarship for post-graduate studies to the first author.

\section{Literature Cited}

Anagnostakis SL (1987) Chestnut blight, the classical problem of an introduced pathogen.

Mycologia 79:23-37.

Chidumayo EN (1997) Miombo ecology and management, 2nd edn. Stockholm Environment Institute, Sweden.

Chipeta ME (1999) Forestry management and sustainable development in southern Africa. South Afr Dev Bull 10:14-17.

Cunningham CW (1997) Can three incongruence tests predict when data should be combined? Mol Biol Evol 14:733-740.

Darlu P, Lecointre G (2002) When does the incongruence length difference test fail? Mol Biol Evol 19:432-437.

Dettman JR, Jacobson DJ, Taylor JW (2003) A multilocus genealogical approach to phylogenetic species recognition in the model eukaryote Neurospora. Evolution 57:2703-2720.

Farris JS, Kallersjo M, Kluge AG, Bult C (1994) Testing significance of incongruence. Cladistics 10:315-319.

Gibson AIS (1981) A canker disease of Eucalyptus new to Africa. FAO, Forest Resources Information 10:23-24.

Glass NL, Donaldson GC (1995) Development of primer sets from filamentous ascomycetes. Appl Environ Microbiol 61:1323-1330.

Gryzenhout M, Myburg H, Van der Merwe NA, Wingfield BD, Wingfield MJ (2004) Chrysoporthe, a new genus to accommodate Cryphonectria cubensis. Stud Mycol 50:119-142.

Gryzenhout M, Myburg H, Wingfield BD, Montenegro F, Wingfield MJ (2005) Chrysoporthe doradensis sp. nov. pathogenic to Eucalyptus in Ecuador. Fungal Divers 20:39-57.

Gryzenhout M, Wingfield BD, Wingfield MJ (2006a) New taxonomic concepts for the important forest pathogen Cryphonectria parasitica and related fungi. FEMS Microbiol Lett 258:161-172.

Gryzenhout M, Rodas CA, Mena Portales J, Clegg P, Wingfield BD, Wingfield MJ (2006b) Novel hosts of the Eucalyptus canker pathogen Chrysoporthe cubensis and a new Chrysoporthe species from Colombia. Mycol Res 110:833-845.

Gryzenhout M, Wingfield BD, Wingfield MJ (2009) Taxonomy, phylogeny, and ecology of barkinfecting and tree killing fungi in the Cryphonectriaceae. APS Press, Minnesota, USA.

Heath RN, Gryzenhout M, Roux J, Wingfield MJ (2006) Discovery of Chrysoporthe cubensis on native Syzygium species in South Africa. Plant Dis 90:443-438. 
Heiniger U, Rigling D (1994) Biological control of chestnut blight in Europe. Phytopathology 32:581-599.

Hodges CS, Alfenas AC, Ferreira FA (1985) The conspecifity of Cryphonectria cubensis and Endothia eugeniae. Mycologia 78:343-350.

Katoh K, Misawa K, Kuma K, Miyata T (2002) MAFFT: a novel method for rapid multiple sequence alignment based on fast Fourier transform. Nucleic Acid Res 30:3059-3066.

McNeill J, Barrie FR, Burdet HM, Demoulin V, Hawksworth DL, Marhold K, Nicolson DH, Prado J, Silva PC, Skog JE, Wiersema JH, Turkland NJ (2007) International Code of Botanical Nomenclature (Vienna Code) adopted by the Seventeenth International Botanical Congress Vienna, Austria, July 2005. Gantner, Ruggell. (Regnum Vegetabile, 146). XVIII, p 568.

Micales JA, Stipes RJ, Bonde MR (1987) On the conspecifity of Endothia eugeniae and Cryphonectria cubensis. Mycologia 79:707-720.

Möller EM, Bahnweg G, Sandermann H, Geiger HH (1992) A simple and efficient protocol for isolation of high molecular weight DNA from filamentous fungi, fruit bodies, and infected plant tissues. Nucleic Acids Res 20:6115-6116.

Muimba-Kankolongo A, Nawa IN, Roux J, Ng'andwe P (2009) Damage to foliage and stems caused by fungal pathogens in young eucalypt plantations in Zambia. South For 71:171-178.

Myburg H, Gryzenhout M, Heath RN, Roux J, Wingfield BD, Wingfield MJ (2002) Cryphonectria canker on Tibouchina in South Africa. Mycol Res 106:1299-1306.

Nakabonge G, Roux J, Gryzenhout M, Wingfield MJ (2006) Distribution of Chrysoporthe canker pathogens on Eucalyptus and Syzygium spp. in Eastern and Southern Africa. Plant Dis 90:734-739.

Nakabonge G, Gryzenhout M, Wingfield BD, Wingfield MJ, Roux J (2007) Genetic diversity of Chrysoporthe cubensis in eastern and southern Africa. S Afr J Sci 103:261-264.

Nutman FJ, Roberts FM (1952) Acute dieback of clove trees in the Zanzibar Protectorate. Ann Appl Biol 39:599-608.

Posada D, Crandall KA (1998) Modeltest: testing the model of DNA substitution. Bioinformatics $14: 817-818$.

Rayner RW (1970) A mycological colour chart. Commonwealth Mycological Institute and British Mycological Society, Kew, Surrey, UK.

Rodas CA, Gryzenhout M, Myburg H, Wingfield BD, Wingfield MJ (2005) Discovery of the Eucalyptus canker pathogen Chrysoporthe cubensis on native Miconia (Melastomataceae) in Colombia. Plant Pathol 54:460-470.

Roux J, Myburg H, Wingfield BD, Wingfield MJ (2003) Biological and phylogenetic analyses suggest that two Cryphonectria species cause cankers of Eucalyptus in Africa. Plant Dis 87:13291332.

Roux J, Meke G, Kanyi B, Mwangi L, Mbaga A, Hunter GC, Nakabonge G, Heath RN, Wingfield MJ (2005) Diseases of plantation forestry tree species in eastern and southern Africa. S Afr J Sci 
101:409-413.

Shakacite O (1991) A review of the pathology of Eucalyptus in Zambia. Research note No. 51. Division of Forest Research, Kitwe, Zambia.

Sinclair WA, Lyon HH (2005) Diseases of trees and shrubs, 2nd edn. Cornell University Press, Ithaca, USA.

Slippers B, Stenlid J, Wingfield MJ (2005) Emerging pathogens: fungal host jumps following anthropogenic introduction. Trends Ecol Evol 20:420-421.

Sokal RR, Rohlf FJ (1995) Biometry: the principles and practices of statistics in biological research, 3rd edn. Freeman, New York.

Swofford DL (2002) PAUP*. Phylogenetic analysis using parsimony *and other methods. Version 4.0b10. Sinauer Associates, Sunderland, Mass.

Van Heerden SW, Wingfield MJ (2001) Genetic diversity of Cryphonectria cubensis isolates in South Africa. Mycol Res 105:94-99.

Vermeulen M, Gryzenhout M, Wingfield MJ, Roux J (2008) Cryphonectriaceae canker pathogens on native and non-native Myrtales in southern Africa. In Proceedings of the XXXIVth Annual Conference of the South African Association of Botanists SAAB 2008 and the VIIth Southern African Society for Systematic Biology SASSB. Drakensville Mountain Resort, KwaZulu-Natal, 13-18 January 2008.

White TJ, Bruns T, Lee S, Taylor J (1990) Amplification and direct sequencing of fungal ribosomal RNA genes for Phylogenetics. In: Innis MA, Gelfand DH, Sninsky JJ, White TJ (eds) PCR protocols: a guide to methods and applications. Academic, San Diego, USA, pp 315-322.

Wingfield MJ (2003) Daniel McAlpine Memorial Lecture. Increasing threat of diseases to exotic plantations in the Southern Hemisphere: lessons from Cryphonectria canker. Australas Plant Pathol 23:133-139.

Wingfield MJ, Swart WJ, Abear BJ (1989) First record of Cryphonectria canker of Eucalyptus in South Africa. Phyophylactica 21:311-313.

Wingfield MJ, Rodas C, Wright J, Myburg H, Venter M,Wingfield BD (2001) First report of Cryphonectria canker on Tibouchina in Colombia. For Pathol31:1-10.

Yang Z (1994) Maximum likelihood phylogenetic estimation from DNA sequences with variable rates over sites: approximate methods. J Mol Evol 39:306-314.

Zimba SC (2005) The contribution of the forestry sector to the copper mining industry in Zambia. Proceedings from the First National Symposium on Timber Industry in Zambia. Mulungushi International Conference Centre. Lusaka, Zambia. 29-30 September 2005. pp 90-94. 